\title{
MYOCD wt Allele
}

National Cancer Institute

\section{Source}

National Cancer Institute. MYOCD wt Allele. NCI Thesaurus. Code C115974.

Human MYOCD wild-type allele is located in the vicinity of $17 p 11.2$ and is approximately

$103 \mathrm{~kb}$ in length. This allele, which encodes myocardin protein, is involved in transcriptional regulation, myogenesis and heart development. 